\title{
PENDEKATAN SAINTIFIK DALAM IMPLEMENTASI KURIKULUM 2013 BERDASARKAN KAJIAN TEORI PSIKOLOGI BELAJAR
}

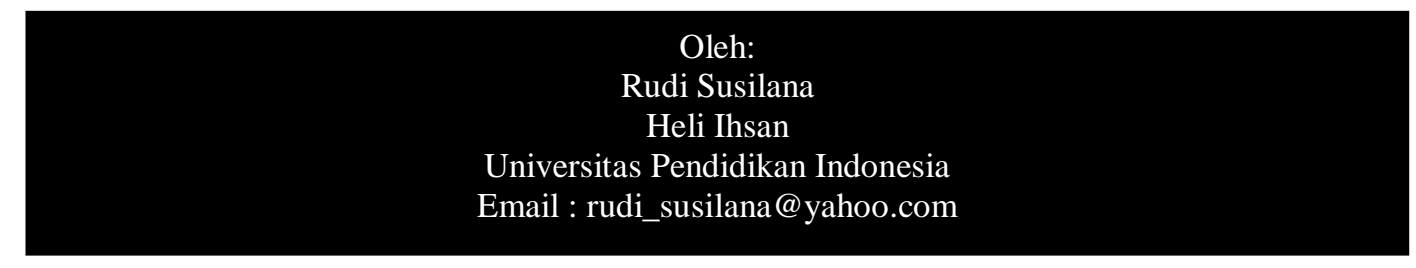

Abstract. The 2013 Curriculum offers a few new things, one of which is the emphasis on the application of the scientific approach. The scientific approach in 2013 Curriculum includes five core activities consisting of several activities as follows: observing, asking, doing, reasoning or associating, and communicating (drawing conclusion, presenting). This paper tries to describe the results of the theoretical studies of psychology of learning about activities developed in the scientific approach and formulate some conclusions that are expected to provide "reinforcement" to the implementers of 2013 Curriculum in various educational units.

Keywords: Scientific Approach, 2013 Curriculum Implementation, Psychology of Learning Theory.

Abstrak. Ada beberapa hal baru dalam pengembangan dan implementasi Kurikulum 2013, salah satunya adalah adanya penekanan penerapan pendekatan saintifik. Pendekatan saintifik dalam Kurikulum 2013 meliputi lima kegiatan inti yang terdiri atas beberapa kegiatan berikut, yaitu: mengamati, menanya, melakukan, menalar atau mengasosiasikan, dan mengomunikasikan (membuat kesimpulan, mempresentasikan).

Paparan ini mencoba memaparkan hasil kajian teori psikologi belajar tentang kegiatankegiatan yang dikembangkan dalam pendekatan saintifik dan merumuskan beberapa simpulan yang diharapkan dapat memberikan "penguatan" kepada para implementator Kurikulum 2013 yang ada di berbagai satuan pendidikan.

Kata Kunci: Pendekatan Saintifik, Implementasi Kurikulum 2013, Teori Psikologi Belajar.

\section{A. PENDAHULUAN}

Salahsatu hal yang banyak ditekankan pada implementasi

Kurikulum 2013 adalah penggunaan pendekatan saintifik dalam pembelajaran. Pendekatan ini sebetulnya bukan barang baru, tetapi "diprioritaskan" untuk dilakukan. Pada implementasi Kurikulum 2013, guru "diwajibkan" untuk melaksanakan kegiatan yang ada dalam pendekatan ingin menyajikan suatu kajian kecil saintifik, sehingga dapat dikatakan jika guru tidak menerapkan kegiatankegiatan dalam pendekatan saintifik, berarti guru tersebut "tidak melaksanakan" Kurikulum 2013.

$$
\text { Paparan ini tidak dimaksudkan dan }
$$
tidak ingin memperdebatkan "keharusan" seorang guru melaksanakan pembelajaran dengan pendekatan saintifik. Paparan ini hanya 
tentang kegiatan-kegiatan yang ada dalam pendekatan saintifik dari kajian psikologi belajar.

Harapan penulis, jika kajian ini dapat dipahami dan rasional untuk dilakukan, maka lakukanlah dengan sebaik-baiknya dalam rangka mengimplemnetasikan Kurikulum 2013. Jika kajian ini dianggap tidak rasional, maka kaji kembali, dan lakukanlah yang terbaik untuk menemukan kegiatan-kegiatan yang dapat membantu guru agar dapat memfasilitasi pembelajaran yang lebih bermutu bagi para anak didiknya.

Kajian ini akan disajikan dalam dua paparan, yang pertama akan memaparkan tentang konsep dasar belajar dan yang kedua akan memaparkan kegiatan-kegiatan dalam pendekatan saintifik berdasakan kajian psikologi belajar. Semoga berguna dan menjadi amal yang bermanfaat.

\section{B. HASIL DAN PEMBAHASAN}

\section{Konsep Dasar Belajar Definisi belajar} Untuk memahami konsep dara dimaksud dalam definisi itu adalah belajar yang dipaparkan selanjutnya, potensi perilaku.

para pembaca diharapkan dapat terlebih dahulu memahami konsep-konsep berikut.

Belajar adalah perubahan yang relatif permanen didalam perilaku yang terjadi karena praktek yang diperkuat (Kimble, 1961). Belajar diukur berdasarkan perubahan perilaku. Hasil belajar harus selalu diartikan sebagai perilaku atau tindakan yang dapat diamati. Setelah belajar, pembelajar akan mampu melakukan sesuatu yang sebelumnya tidak bisa dilakukan sebelum mereka belajar. Definisi belajar yang tertuju kepada perilaku itu selanjutnya berubah seiring dengan kajian-kajian atau datangnya teori-teori baru tentang belajar. Belajar, kemudian, diartikan tidak hanya terbatas pada perilaku tetapi juga terjadi pada proses sebelum terjadinya perubahan perilaku. Apa itu sebelum terjadi perubahan perilaku? Potensi perilaku. Learning ...as any relatively permanent change in an organism's behavioral reportoire that occurs as a result of of exeperiences (Wiitig, 1981:2). Behavioral repertoire yang 
Edutech, Tahun 13, Vol.1, No.2, Juni 2014

Seorang pembelajar bisa jadi tidak sebagai hasil atau akibat dari menunjukkan perubahan perilaku pengalaman dan mendahului perubahan karena dia belum ada kesempatan atau perilaku. Jika digambarkan dalam waktu untuk menunjukkan perubahan bentuk variabel dalam sebuah perilaku itu. Dia tidak memperlihatkan penelitian, belajar adalah variabel perubahan perilakunya untuk bisa intervening atau variabel perantara diamati bukan berarti dia tidak bisa, antara variabel independen dan tidak tahu, atau tidak mampu atau dia dependen. Sebagai variabel independen tidak belajar. Jadi definisi belajar dan dependen adalah pengalaman dan berkembang menjadi suatu yang terjadi perubahan perilaku (Hegenhahn, 2010).

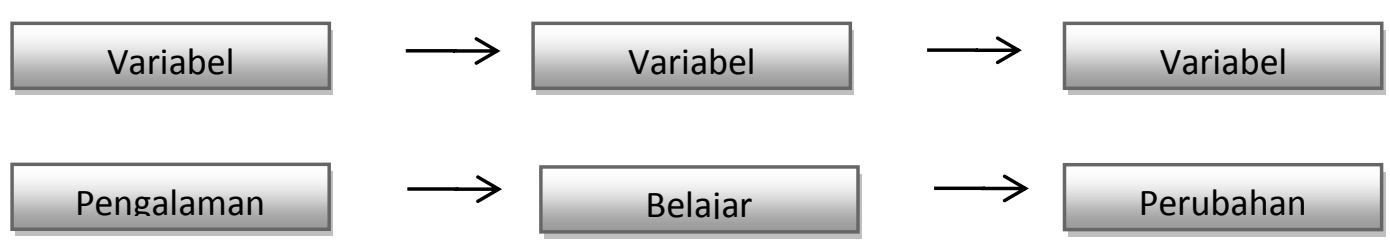

Gambar 1 Keterkaitan antara pengalaman, belajar, dan perubahan perilaku.

Pengalaman adalah aktivitas- yang mempengaruhi potensi perilaku aktivitas yang dilakukan pembelajar, atau perilaku menjadi meningkat atau seperti praktik penguatan, hubungan semakin kuat (Cherry, tt). Misalnya, antara stimulus dan respons, atau anak mampu membaca buku, kemudian akuisisi informasi (Hegenhahn, 2010). anak diberi hadiah agar semakin minat Perubahan perilaku yang terlihat membaca buku. Penguatan ada dua disebut sebagai tindakan atau performa yaitu penguatan positif dan penguatan (Wiitig, 1981:2).

Praktik penguatan adalah peristiwa apapun yang mampu meningkatkan atau menjaga kekuatan respons...any event that increases or maintains the strength of response (Wittig,1981:78). Jadi penguatan adalah segala sesuatu negatif. Penguatan positif adalah menghadirkan sesuatu agar respons meningkat. Misalnya, guru akan memberi tugas kedua jika tugas pertama selesai. Contoh di atas adalah contoh penguatan positif. Sementara penguatan negatif adalah menghilangkan sesuatu agar respons 
meningkat. Misalnya, seorang guru menugaskan pekerjaan rumah kepada para siswa, jika para siswa tidak menyelesaikan pekerjaan rumah maka kuis tidak diberikan oleh guru sehingga nilai yang dimiliki oleh siswa berkurang (Cherry, tt).

$\begin{array}{rrr}\text { Akuisisi } & \text { informasi } & \text { adalah } \\ \text { pemerolehan } & \text { informasi } & \text { yang }\end{array}$
melibatkan pengingatan informasi dalam sistem saraf....acquisition is a process that involves experiencing something with that experience leading to the development of an ensuing trace of ensuing trace of the event in the nervous system of the organism (Wittig, A.F.,1981:78). Jadi, masukan informasi yang kemudian diproses oleh otak disebut sebagai akuisisi informasi.

Sementara memori adalah proses mengingat yang dilakukan oleh otak yang dibuktikan dengan diucapkan, ditulis, dan sebagainya.

2. Kajian Pembelajaran Saintifik berdasarkan Teori Psikologi Belajar

Untuk mengaji metode saintifik dalam proses pembelajaran ini akan digunakan analisis proses belajar yang telah dipaparkan di atas, yaitu: pengalaman mempengaruhi belajar dan belajar mempengaruhi perilaku. Akan dikaji mana kegiatan dalam pendekatan saintifik ini yang merupakan pengalaman?, pengalaman yang terjadi berupa pengalaman apa? Mana yang merupakan hasil belajar? dan apakah terdapat perubahan perilaku dalam pendekatan saintifik ini?

Dalam pendekatan saintifik ada beberapa tahap/ kegiatan, yaitu: Observing, Questioning, Associating, Experimenting,

Processing, Conclusing, Presenting. Observing adalah proses mengamati suatu fakta. Questioning adalah proses menanyakan atau membuat hipotesis segala sesuatu seputar fakta yang diamati. Associating adalah menalar atau melakukan asosiasi antara yang diketahui sebelumnya dengan apa yang baru diketahui. Experimenting adalah menguji pertanyaan-pertanyaan atau hipotesis yang muncul dalam questioning. Processing adalah kegiatan yang dilakukan untuk merumuskan pengetahuan yang diperoleh dari empat proses sebelumnya. Conclusing adalah merumuskan atau menyimpulkan pengetahuan yang diperoleh. 
Edutech, Tahun 13, Vol.1, No.2, Juni 2014

Presenting adalah menyajikan pengetahuan yang diperoleh kepada orang lain.

Dalam kerangka proses belajar berbagai kegiatan yang merupakan manifestasi pengalaman, yaitu observing, questioning, associating, experimenting, dan processing. Satu kegiatan adalah hasil belajar, yaitu: conclusing, dan satu kegiatan terakhir adalah perubahan perilaku atau performa, yaitu: presenting.

\section{Observing (Mengamati)}

Observasi adalah kegiatan paling utama dari manusia. Observasi adalah ujung tombak pengetahuan manusia. Manusia dengan inderanya mengamati lingkungan sekitar baik alam maupun lingkungan sosial dan kebudayaan untuk membentuk pengetahuan yang akan menjadi modal dia bertahan dalam hidup. Semakin dia memahami dan mengetahui lingkungan sekitarnya maka dia akan semakin bertahan (Hergenhahn, 2010). Menurut Guthrie (1959), apa-apa yang dilihat akan menjadi sinyal apa-apa yang
dilakukan.Apa yang diamati adalah awal apa yang dipelajari.

Vigotsky menyatakan bahwa lingkungan atau kebudayaan yang dimiliki oleh lingkungan dimana seseorang hidup adalah yang membentuk pengetahuan orang itu tentang dunia (Ormrord, 2008; Santrock, 2011). Orang akan mengetahui suatu pengetahuan karena pengetahuan itu disampaikan oleh lingkungannya kepadanya atau dia mengamati bagaimana lingkungannya menciptakan pengetahuan itu. Selain itu menurut Piaget (Ormrord, 2008) anak-anak mengonstruksi pengetahuan mereka berdasarkan pengalaman. Anakanak menggabungkan pengalaman-pengalaman mereka dari penggalanpenggalan fakta yang mereka amati. Dari situ anak akan memahami atau memiliki pandangan bagaimana cara kerja dunia di sekitar mereka. Menurut Piaget juga anak-anak adalah pembelajar yang aktif 
Edutech, Tahun 13, Vol.1, No.2, Juni 2014

yang selalu tertarik untuk mengamati agar bisa mamahami dunia. Jadi pengamatan adalah awal mula pembentukan pengetahuan mereka. Observasi ini termasuk dalam pengalaman akuisisi informasi.

Obyek observasi jika merujuk definisi Vigotsky

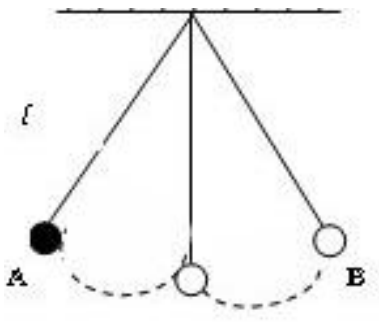

Gambar 2. Proses belajar melalui pengamatan

Seorang siswa tengah mengamati dua bandul. Dari pengamatan ini ada tiga informasi yang diterima anak itu terhadap dua bandul yang berbeda itu. Dua-duanya memiliki berat bandul yang sama yaitu 100g. Bandul pertama memiliki panjang tali bandul yang lebih panjang daripada bandul kedua. Disamping itu bandul pertama tentang pengetahuan bisa berupa pengetahuan tentang alam dan perilaku manusia atau kebudayaan. Obyek alam yang diamati contohnya adalah bandul yang dijelaskan dibawah. Sementara contoh perilaku manusia atau kebudayaan adalah kemampuan seorang penyanyi yang sedang tampil diatas panggung.

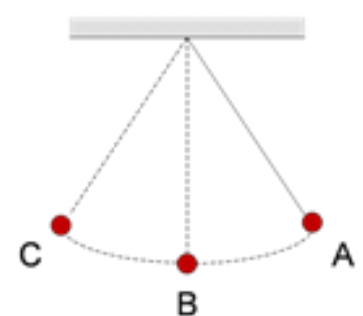

lebih lama bandulannya dalam satu kali bandulan daripada bandul ke dua.

2. Questioning

(MenanyaBertanya)

Menurut Piaget, anak-anak seringkali mengalami ekuilibrium atau keseimbangan karena mereka mampu menafsirkan dan merespons peristiwa-peristiwa atau fakta- 
Edutech, Tahun 13, Vol.1, No.2, Juni 2014

fakta yang mereka temui dengan pengalamanpengalaman sebelumnya. Pengalaman sebelumnya ini disebut sebagai skema. "Skema adalah potensi untuk bertindak dengan cara tertentu"(Hegenhahn,

2010:314). Akan tetapi seringkali anak-anak mengalami kondisi

disekuilibrium atau

ketidakseimbangan.

Disekuilibrium ini dialami jika skema atau pengalaman yang dimiliki sebelumnya tidak mampu menafsirkan, memahami, atau merespons apa yang diamatinya. Ketika mereka mengalami ini maka mereka akan mengajukan pertanyaan-pertanyaan yang jika pertanyaan-pertanyaan itu terjawab maka mereka tidak akan mengalami disekuilibrium lagi. Proses perubahan disekuilibrium ke ekuilibrium maupun sebaliknya disebut sebagai ekuilibrasi.

\section{Pertanyaan-pertanyaan}

yang mungkin diajukan oleh anak itu ketika mengamati dua bandul tersebut adalah mengapa bandul pertama lebih lama daripada bandul kedua? Apakah periode (waktu yang ditempuh dalam satu bandulan) bandul pertama disebabkan oleh panjang tali? Dan hipotesis yang bisa diajukan untuk dipecahkan adalah panjang tali mempengaruhi tingkat periode bandulan.

\section{Associating}

Menurut Piaget (Ormrord, 2008), anak-anak memahami suatu fakta atau peristiwa berdasarkan pengalaman yang dimiliki sebelumnya. Apa-apa yang ditangkap oleh indera atau diamati akan dipikir atau dinalar untuk memahami fakta itu. Gabungan fakta-fakta dan konsep-konsep baru dan lama akan membentuk konsepkonsep atau pengetahuan baru lagi. Kemampuan anak-anak berpikir tergantung kepada perkembangan kognitifnya. Semakin tinggi usia anak semakin bisa menggunakan analisis yang kompleks. Jadi 
Edutech, Tahun 13, Vol.1, No.2, Juni 2014

obyek yang diamati atau yang akan dipelajari harus memperhatikan perkembangan kognitif mereka. Pada usia lebih muda jangan diberi obyek pengamatan yang rumit dan kompleks.

Dalam proses penalaran ini terjadi proses selecting dan connecting, dua istilah yang dibuat oleh tokoh Psikologi Belajar Thorndike (Hegenhahn, 2010). Siswa akan melakukan selecting yaitu memilih-milih hal-hal yang menarik atau berbeda dari apa yang diamati. Setelah menemukan hal-hal yang berbeda atau yang sama maka siswa akan melakukan connecting atau mengaitkan hal-hal itu menjadi suatu pengetahuan baru. Proses selecting yang terjadi adalah siswa mengamati bahwa ada dua hal yang menarik atau berbeda antara dua bandul itu yaitu panjang tali dan gerakan bandul.

$\begin{array}{lr}\text { Setelah } & \text { anak-anak } \\ \text { mengajukan } & \text { pertanyaan- } \\ \text { pertanyaan } & \text { dalam }\end{array}$

pengajuan pertanyaan, anakanak akan mencoba menjawabnya dengan menalar pengetahuan lama dan baru. Mereka akan membuat konsep baru yang sekiranya sesuai dengan apa yang diamatinya. Pertanyaan: mengapa bandul pertama lebih lama periodenya dari bandul kedua? Akan dijawab dengan mengamati fakta bahwa ada perbedaan panjang tali bandul antara dua bandul sehingga mereka memilih panjang tali sebagai variabel yang menentukan lama atau tidaknya bandulan. Dari pengamatan bahwa bandul yang talinya lebih panjang ternyata lebih lama waktu bandulnya sementara tali bandul yang lebih pendek gerakannya lebih cepat atau pendek.

Untuk sementara mereka akan memahami atau membuat konsep atau pengetahuan bahwa semakin panjang bandul akan semakin memperlambat gerakan bandul. Pemahaman ini akan membuat siswa siap untuk melakukan suatu tindakan jika 
Edutech, Tahun 13, Vol.1, No.2, Juni 2014

menemui kondisi yang sama.

Kesiapan siswa ini sangat mempengaruhi hasil belajar.

Menurut Thorndike pembelajar yang siap untuk melakukan suatu tindakan maka akan menghasilkan rasa puas setelah melakukan tindakan itu. "Apabila satu unit konduksi siap untuk menyalurkan (to conduct), maka penyaluran dengannya akan memuaskan" (Gergenhahn, 2010:64)

4. Experimenting

Praktik atau latihan sangat penting dalam pengalaman belajar. Throndike dan Guthrie membuat teori yang sama bahwa praktik atau latihan akan meningatkan performa. "Koneksi antara stimulus dan respons akan menguat saat dipakai. Dengan kata lain, melatih koneksi (hubungan) antara situasi yang mengstimulasi dengan suatu respons akan memperkuat koneksi antara keduanya" (Gergenhahn, 2010:65). Untuk itu sangatlah penting untuk siswa mempraktikkan atau melatih apa yang dipahami sebelumnya. Latihan ini akan semakin memperkuat proses belajar. Dengan latihan ini akan semakin memperkuat koneksi antara stimulus dan respons. Semakin sering terjadi koneksi antara stimulus dan respons maka akan semakin memperkuat memori.

Dalam eksperimen ini siswa ingin membuktikan apakah benar panjang tali adalah variabel yang mempengaruhi gerak bandul. Dalam eksprimen ini siswa bisa membuat satu bandul lagi yang talinya lebih panjang dari bandul pertama atau yang lebih pendek dari bandul bandul kedua. Misalnya saja siswa membuat bandul ketiga yang talinya lebih panjang dari bandul pertama. Setelah itu bandul ketiga ini dicoba dibandulkan dan diamati atau diukur apakah bandul ketiga ini lebih lama dari bandul pertama. Jika hasilnya bandul ketiga ini lebih lama maka pemahaman sebelumnya bahwa semakin 
Edutech, Tahun 13, Vol.1, No.2, Juni 2014

panjang tali bandul akan semakin lama bandulannya akan terbukti dalam eksperimen ini. Sekali lagi siswa mengalami sebuah pengalaman baru dari sebelumnya yang semakin memperkuat pemahaman siswa tentang bandul.

\section{Processing}

Processing adalah kegiatan merumuskan pengetahuan yang dialami sebelumnya. Perumusan pengetahuan ini dilakukan secara kolaboratif. Pembelajaran kolaboratif memiliki kelebihan daripada pembelajaran lainnya. Dalam pembelajaran kolaboratif siswa akan menguji apakah pengetahuan yang dimilikinya sama dengan teman atau guru. Pembelajaran ini akan membawa siswa kepada pemahaman yang sama dengan lingkungannya. Sesuai dengan pendapat Vigotsky bahwa kemampuan kognitif berasal dari relasi sosial dan dipengaruhi oleh sosiokultural (Santrock, 2011).
Sekalipun guru dalam pembelajaran kolaboratif sangat penting karena guru adalah orang yang menguasai pengetahuan lebih baik dari siswa, teman sebaya juga memiliki peran penting yang berbeda. Guru akan sangat tepat jika anak sedang dihadapkan pada tugas-tugas atau prosedur yang yang kompleks (Gauvian dalam Ormrord, 2008). Sementara belajar dengan teman sebaya memiliki manfaat-manfaat sebagai berikut: 1) dengan diskusi dengan teman-teman yang memiliki perspektif yang beragam maka siswa akan menguasai pemahaman yang lengkap tentang suatu topik, 2) kendati bisa jadi diskusi itu akan ada perdebatan atau ketidaksetujuan, anak-anak bisa menginternalisasi proses argumentasi tersebut sehingga memperoleh kemampuan untuk melihat situasi-situasi lain dari beragam sudut pandang, 3) anak seringkali mampu menyelesaikan tugas-tugas yang lebih sulit saat mereka bekerja 
Edutech, Tahun 13, Vol.1, No.2, Juni 2014

bersama-sama alih-alih bekerja sendiri,

4) anak-anak mempelajari perilaku-perilaku sosial yang bernilai, misalnya, bagaimana merencanakan suatu kegiatan bersama, bagaimana mengkoordinasikan peran yang berbeda-beda, dan sebagainya, ketika mengerjakan tugas-tugas kognitif bersama rekan-rekan sebayanya (Gauvain dalam Ormrod, 2008).

6. Conclusing

Kesimpulan adalah pengetahuan yang diperoleh setelah siswa menjalani proses pengalaman belajar. Pengetahuan inilah disebut sebagai potensi perilaku (Hegenhahn, 2010). Potensi ini akan mendorong muculnya perilaku pada saat yang tepat atau dibutuhkan.

7. $\quad$ Presenting

Presenting adalah tahap akhir dari proses belajar dalam pendekatan saintifik. Presenting inilah yang disebut perilaku belajar atau perubahan perilaku yang terjadi setelah menjalani proses belajar. Sekalipun ini masuk perubahan perilaku, dalam kegiatannya bisa menjadi sebuah pengalaman belajar baru karena dalam aktivitasaktivitasnya ada penguatanpenguatan. Dalam kegiatan ini siswa menyajikan laporan atau menampilkan dalam bentuk presentasi lisan dari hasil belajarnya. Penyajian laporan oleh siswa akan diberi nilai atau feedback oleh guru. Nilai dan feedback ini adalah penguatan. Penguatan adalah peristiwa yang bisa menjaga atau meningkatkan respons.

Penguatan ada dua, yaitu penguatan positif dan negatif. Dengan penguatan ini diharapkan motivasi dan kemampuan siswa akan bertahan lama. Pemberian nilai yang memuaskan siswa atau feedback yang baik misalnya pujian adalah penguatan positif. Penguatan positif adalah ... "involves the addition of something to increase a response, such as giving a bit of candy to a child after she cleans 
Edutech, Tahun 13, Vol.1, No.2, Juni 2014

up her room" (Cherry, tt). Sementara nilai yang jelek adalah punishment atau hukuman yang bertujuan agar kemampuannya yang jelek itu tidak muncul lagi di masa yang akan datang. Atau motivasi belajarnya yang rendah akan meningkat menjadi motivasi tinggi. Ini disebut Positive Punishment, yaitu memberi hukuman agar perilaku yang tidak diinginkan "menghilang“"

Dengan nilai yang baik ini, diharapkan peserta didik tetap semangat atau semakin meningkat motivasi belajarnya. Menurut Thorndike (Hegenhahn,2010) sebuah perilaku yang benar atau diinginkan jika diberi penguatan berupa penghargaan maka akan menjadi kebiasaan.

\section{SIMPULAN}

Berdasarkan hasil kajian psikologis di atas, dapat dirumuskan beberapa kesimpulan sebagai berikut.

$\begin{array}{lr}\text { 1. Kegiatan-kegiatan yang } \\ \begin{array}{l}\text { dikembangkan } \\ \text { pendekatan saintifik }\end{array} & \text { dapatam }\end{array}$

memicu muncul dan terciptanya berbagai pengalaman belajar yang diperoleh siswa dengan melibatkan seluruh panca indera, fisik, dan psikis siswa sehingga membantu mengembangkan berbagai potensi yang dimilikinya.

2. Penerapan pendekatan saintifik dapat membantu guru mengembangkan kegiatan pembelajaran yang lebih bervariasi untuk memfasilitasi siswa mengoptimalkan pengembangan potensi yang dimilikinya sehingga membantu mengoptimalkan perolehan hasil belajarnya.

3. Penerapan pendekatan saintifik dalam implementasi Kurikulum 2013, selain dapat membantu menciptakan pembelajaran yang memenuhi standar proses sehingga dapat meningkatkan kualitas pembelajaran yang dilaksanakan oleh guru, juga dapat membantu pencapaian tujuan pembelajaran dan pendidikan yang utuh, meliputi: sikap (sikap religius dan sikap 
Edutech, Tahun 13, Vol.1, No.2, Juni 2014

sosial), pengetahuan, dan Ormrod, J.E., (2008), Psikologi keterampilan. Pendidikan, (Indianti, W, Terj.).

\section{DAFTAR PUSTAKA} Jakarta:Erlangga. (Buku asli diterbitkan tahun 2004)

Cherry, K ., (tt) What is Reinforcement.

Diterima dari

http://psychology.about.com.

Hegenhahn, B.R. \& Olson, M.H., (2010), Theories of Learning (7th ed.) (Wibowo B.S.,T, Terj.), Jakarta: Kencana (Buku asli diterbitkan tahun 2008)

Kemdikbud., (2013), Modul Pelatihan

Guru; Implementasi Kurikulum 2013.

Kimble, G.A., (1961). Hilgard and Marquis' conditioning and learning (2nd ed.) Englewood Cliffs, NJ: Prentice Hall.

Santrock, J.W .,(2011), Psikologi Pendidikan (Wibowo B.S.,T, Terj.), Jakarta:Kencana. (Buku asli diterbitkan tahun 2004)

Snow, Richard E.\& Jackson, Douglas N., (1993), Assessment of Conative Constructs for Educational Research and Evaluation: A Catalogue. California: NCRESST.

Wittig, A.F.,(1981), Psychology of Learning, New York:McGrawHill Book Company. 